\title{
Plasma Immunoreactive Gamma Melanotropin in Patients with Idiopathic Hyperaldosteronism, Aldosterone-producing Adenomas, and Essential Hypertension
}

\author{
George T. Griffing, Brian Berelowitz, Margo Hudson, Robert Salzman, \\ Jo Ann E. Manson, Steven Aurrechia, and James C. Melby \\ Section of Endocrinology and Metabolism, Evans Memorial Department of Clinical Research and the Department of Medicine, \\ University Hospital and Boston University School of Medicine, Boston, Massachusetts 02118
}

Robert C. Pedersen and Alexander C. Brownie

Departments of Biochemistry and Pathology, Schools of Medicine and Dentistry, State University of New York at Buffalo, Buffalo, New York 14214

\begin{abstract}
A non-ACTH aldosterone-stimulating factor(s) has been implicated in the pathogenesis of idiopathic hyperaldosteronism (IHA). Although this factor has not been fully characterized, some evidence suggests that it may be related to a pro- $\gamma$ melanotropin (pro- $\gamma$-MSH), derived from the $\mathrm{NH}_{2}$-terminal region of pro-opiomelanocortin. In the present study, plasma immunoreactive (IR-) $\boldsymbol{\gamma}$-MSH levels at $0800 \mathrm{~h}$ in patients with IHA were evaluated $(90 \pm 17 \mathrm{fmol} / \mathrm{ml}$; range: $13-173 \mathrm{fmol} / \mathrm{ml})$ and found to be significantly higher $(P<0.05)$ than those in subjects with aldosterone-producing adenomas (33 $\pm 8 \mathrm{fmol} /$ $\mathrm{ml}$ ), essential hypertension $(33 \pm 6 \mathrm{fmol} / \mathrm{ml})$, and normotensive controls $(19 \pm 2 \mathrm{fmol} / \mathrm{ml})$. Seven of nine IHA subjects had circulating IR- $\gamma$-MSH levels above the normal range ( $>35$ fmol/ml). In plasmas sampled at $1200 \mathrm{~h}$, IR- $\gamma$-MSH was significantly higher in patients with IHA $(95 \pm 26 \mathrm{fmol} / \mathrm{ml})$ and adenomas (63 $\pm 23 \mathrm{fmol} / \mathrm{ml})$, as compared with essential hypertensives $(31 \pm 6 \mathrm{fmol} / \mathrm{ml})$ and normotensives $(19 \pm 3 \mathrm{fmol} / \mathrm{ml})$. Mean plasma IR-ACTH, plasma cortisol, and urinary cortisol levels did not differ significantly between any of these groups. In order to evaluate the effect of a pro- $\gamma$-MSH in vitro, adrenal adenoma tissue was obtained from two patients, one with elevated IR- $\gamma$-MSH $(61 \mathrm{fmol} / \mathrm{ml})$ and a second with low IR$\gamma$-MSH $(12 \mathrm{fmol} / \mathrm{ml})$. Aldosterone secretion by dispersed adenoma cells from the former, but not the latter, underwent a fourfold dose-dependent $\left(10^{-14}-10^{-9} \mathrm{M}\right)$ increase in response to human Lys- $\gamma 3$-MSH. These data suggest that a pro- $\gamma$ MSH may be implicated as a pathogenic factor in a subset of patients with primary aldosteronism, particularly among those differentially diagnosed as having IHA.
\end{abstract}

\section{Introduction}

There is mounting evidence that a non-ACTH pituitary factor(s) may be involved in the regulation of aldosterone secretion.

This paper was presented in part at the Plenary session of the American Society for Clinical Investigation, 1984, in Washington, DC (Clin. Res. 32:261A. [Abstr.]), and at the Seventh International Congress of Endocrinology, 1984, in Quebec City, Canada.

Address reprint requests to Dr. Melby.

Received for publication 2 November 1984 and in revised form 8 February 1985.

J. Clin. Invest.

(c) The American Society for Clinical Investigation, Inc. 0021-9738/85/07/0163/07 \$1.00

Volume 76, July 1985, 163-169
Major support for this hypothesis comes from investigations of idiopathic hyperaldosteronism (IHA), ${ }^{1}$ a variant in primary aldosteronism $(1,2)$. Patients with IHA have increased levels of a circulating glycoprotein termed aldosterone-stimulating factor (ASF) (3-5). This finding may explain the bilateral adrenal hyperplasia and increased aldosterone production associated with IHA. Although the characterization of ASF is incomplete, it has been localized to the pituitary by immunohistochemical staining (6). A number of pituitary polypeptide candidates have been evaluated for ASF-like activity, including several that are derived from pro-opiomelanocortin (POMC): $\alpha$-melanotropin, melanocyte-stimulating hormone ( $\alpha$-MSH) $(7,8), \beta$-MSH/ $\beta$-lipotropin $(9-12)$, and $\beta$-endorphin $(13,14)$. Interest has also focused on the glycosylated $\mathrm{NH}_{2}$-terminal segment of POMC, which includes the $\gamma$-MSH sequence (15), and which can be cleaved at several sites to generate a small group of pro- $\gamma$-MSHs. Various of these pro- $\gamma$-MSHs have been shown to stimulate aldosterone secretion by dispersed aldosteronoma cells (16); to potentiate aldosterone secretion in vitro (17) and in vivo (18); and to exhibit hyperplastic and hypertrophic effects on the adrenal cortex (19). The present study was undertaken to evaluate the circulating levels of immunoreactive- (IR-) $\boldsymbol{\gamma}$-MSH in patients with IHA, aldosterone-producing adenomas (APA), and essential hypertension (EH), as compared with normotensive controls (NC).

\section{Methods}

Subjects. Four groups of subjects were studied: IHA (total/females9/5; $\times$ age $-51 \mathrm{yr} ; \times$ weight $-188 \mathrm{lb})$; APA (5/2; $49 \mathrm{yr} ; 154 \mathrm{lb}) ; \mathrm{EH}$ (9/6; $49 \mathrm{yr} ; 173 \mathrm{lb}) ; \mathrm{NC}(7 / 4 ; 32 \mathrm{yr} ; 144 \mathrm{lb})$.

All hypertensive patients underwent a 7-d protocol in a metabolic unit before diagnosis. Medications influencing the renin-aldosterone or pituitary-adrenal systems, including diuretics, adrenergic-blockers, vasodilators, and estrogens, were discontinued for at least 4 wk preceding admission. Where required, prazosin (1-10 mg/d) (20) was the primary antihypertensive therapy. After admission to the metabolic unit, patients were given a fixed isocaloric diet containing $128 \mathrm{meq}$ $\mathrm{Na}^{+}$and 80 meq $\mathrm{K}^{+} / \mathrm{d}$. After one to two days of electrolyte equilibration, a 24-h urine sample was collected for measurement of aldosterone secretion rate (ASR), cortisol, tetrahydroaldosterone, electrolytes, and

1. Abbreviations used in this paper: AI, angiotensin I; APA, aldosteroneproducing adenoma; ASF, aldosterone-stimulating factor; ASR, aldosterone secretion rate; EH, essential hypertension; IHA, idiopathic hyperaldosteronism; IR, immunoreactive; KRBGA, Krebs-Ringer bicarbonate/glucose/albumin buffer, MSH, melanotropin, melanocytestimulating hormone; NC, normotensive controls; POMC, pro-opiomelanocortin; PRA, plasma renin activity. 
creatinine. After $8 \mathrm{~h}$ of recumbancy, plasma was collected at $0800 \mathrm{~h}$ while the patient was supine and again at $1200 \mathrm{~h}$ after $4 \mathrm{~h}$ of upright posture. On a subsequent day plasma was collected $(1100 \mathrm{~h})$ at $3 \mathrm{~h}$ after upright posture and furosemide $(80 \mathrm{mg}$, oral). Additional diagnostic testing included an adrenal iodocholesterol scan (NP-59), computerized axial tomography of the abdomen $(21,22)$, and selective adrenal vein catheterization, if necessary.

The diagnosis of hypertension was established by two or more diastolic blood pressures $>90 \mathrm{mmHg}$, or systolic blood pressures $>140 \mathrm{mmHg}$ (23). The diagnosis of IHA was established by the following criteria: hypertension; spontaneous hypokalemia; suppressed plasma renin activity (PRA) ( $<1.5 \mathrm{ng}$ angiotensin I [AI]/ml per h); elevated ASR ( $>150 \mathrm{ml} / \mathrm{d}$ ); postural aldosterone increment $25 \%$ above the supine level; plasma 18-hydroxycorticosterone level $<100 \mathrm{ng} / \mathrm{dl}$ at $0800 \mathrm{~h}$ (24); nonlateralizing selective adrenal vein aldosterone sampling; and symmetric adrenal morphology on abdominal computerized axial tomographic scanning.

Analytical methods. Cortisol, 18-hydroxycorticosterone, aldosterone, and PRA were measured by standard assay techniques (24-27). To assess ASR, $\left[{ }^{3} \mathrm{H}\right]$ aldosterone was injected and the standard activity of urinary metabolites was calculated after derivitization and chromatography, as previously described (28).

IR- $\boldsymbol{\gamma}$-MSH was determined by direct radioimmunoassay (RIA) on $50-\mu 1$ aliquots of plasma. The procedure has been described previously for assay of IR- $\gamma$-MSH in rat plasma (29), but differed here in the elimination of the SepPak extraction step. This was deemed feasible, because dilutions of human plasma samples consistently exhibited displacement in parallel with assay standards. The antiserum is directed against the $\mathrm{COOH}$-terminal end of $\gamma$-MSH and shows no significant cross-reactivity with $\alpha$ - or $\beta$-MSH, human $\beta$-lipotropin, ACTH, or $\beta$ endorphin (29). Standards and radioiodinated tracer (29) were prepared from synthetic human Lys- $\gamma 3$-MSH (30) (courtesy of Dr. N. Ling, The Salk Institute, La Jolla, CA). The detection limit of the assay was $0.3 \mathrm{fmol}$ of standard, and $50 \%$ tracer displacement occurred in the presence of $10 \mathrm{fmol}$. The in-run and between-run coefficients of assay variation were 3.1 and $8.8 \%$, respectively. Our established upper limit of the normal range for human plasma IR- $\gamma$-MSH in this assay was $35 \mathrm{fmol} / \mathrm{ml}(n=45)$, in close agreement with that reported by another group (31).

IR-ACTH was measured by RIA essentially as described by Nicholson et al. (32) on unextracted aliquots (20-50 $\mu$ l) of plasma using a commercial antiserum (IgG Corp., Nashville, TN) of high affinity. The antiserum did not cross-react significantly with $\alpha-, \beta$-, or pro- $\gamma$ MSHs, CLIP, $\beta$-lipotropin, or $\beta$-endorphin. Human ACTH(1-39) (Bachem, Inc., Torrance, CA) was used for standards and tracer, and radioiodination was accomplished using Iodogen (29). In our hands, the detection limit of the assay was $0.06 \mathrm{fmol}$ ACTH, with $50 \%$ tracer displacement at $\sim 1.0 \mathrm{fmol}$. For both IR- $\gamma-\mathrm{MSH}$ and IR-ACTH determinations, the samples were run in duplicate or triplicate. Randomly selected samples were run at three dilutions to confirm parallel displacement in the assays.

Dispersion and incubation of adrenal cells. Tissue was obtained from two APA patients undergoing unilateral adrenalectomy. Approximately $1 \mathrm{~g}$ of tissue from each tumor was grossly dissected and minced. Cell dispersion was then carried out as follows. Each mince was incubated separately for $50 \mathrm{~min}$ at $37^{\circ} \mathrm{C}$ in Krebs-Ringer bicarbonate/ glucose/albumin buffer (KRBGA) $\left(140 \mathrm{mM} \mathrm{Na}{ }^{+}, 4.9 \mathrm{mM} \mathrm{K}^{+}, 2 \mathrm{mg} /\right.$ $\mathrm{ml}$ glucose, and $40 \mathrm{mg} / \mathrm{ml}$ bovine serum albumin; $\mathrm{pH}$ 7.40) containing $3.7 \mathrm{mg} / \mathrm{ml}$ collagenase (Worthington Biochemicals, Freehold, NJ) and $50 \mu \mathrm{g} / \mathrm{ml}$ DNase I (Sigma Chemical Co., St. Louis, MO). Tissue fragments were then disrupted by gentle trituration, filtered through a fine platinum mesh, and centrifuged $\left(10 \mathrm{~min}, 100 \mathrm{~g}\right.$ at $\left.4^{\circ} \mathrm{C}\right)$. The pellets were resuspended and washed in KRBGA thrice in this manner. Final resuspension and incubation were carried out in KRBGA supplemented with $0.2 \mathrm{mg} / \mathrm{ml} \mathrm{L-glutamine}$ and $1.34 \%$ (vol/vol) each of Eagle's basal and modified nonessential amino acid media (Gibco Laboratories, Grand Island, NY). Incubations were in polypropylene vials for $2 \mathrm{~h}$ at $37^{\circ} \mathrm{C}$ under an atmosphere of $95 \% \mathrm{O}_{2} / 5 \% \mathrm{CO}_{2}$. Each vial contained $1.9 \mathrm{ml}$ of suspension $\left(6.0 \times 10^{4}\right.$ cells $)$ and $0.1 \mathrm{ml}$ of test solution. The latter consisted of ACTH(1-24) (Organon of Canada, Ltd., Ontario, Canada) or synthetic human Lys- $\gamma 3-\mathrm{MSH}$, which was reconstituted just before addition with peptide diluent $(0.15 \mathrm{M} \mathrm{NaCl}$ containing $1 \mathrm{mg} / \mathrm{ml}$ bovine serum albumin, adjusted to $\mathrm{pH} 2.3$ with $1 \mathrm{~N} \mathrm{HCl}$ ). After incubation, the cells were centrifuged and the medium was removed for determination of aldosterone.

Statistical analysis. Where appropriate, results are expressed as $\mathrm{x} \pm \mathrm{SE}$. Multiple comparisons were carried out by analysis of variance using Dunnett's modified $t$ test $(33,34)$. Comparisons between two means were performed using unpaired $t$ test. A nonparametric KrushallWallis one-way analysis of variance by ranks and Mann-Whitney $U$ test for two independent samples was also used for statistical inferences. Rejection of the null hypothesis was at a probability of $P<0.05$.

\section{Results}

Blood pressures were comparable among the three hypertensive groups, while the potassium levels were low in IHA and APA as compared with normal levels in EH (Table I). All patients with primary aldosteronism (IHA and APA) had suppressed upright and postfurosemide PRA ( $<1.5 \mathrm{ng} \mathrm{AI} / \mathrm{ml}$ per $\mathrm{h})$ and elevated ASR ( $>150 \mu \mathrm{g} / \mathrm{d})$. To distinguish IHA from APA, at least three of the following differential diagnostic criteria were applied (Table II): (a) postural plasma aldosterone increment $>25 \%$ above the corresponding supine value $(35,36)$ in IHA $(n=7$ of 9 ) but not in APA (1/5); (b) plasma 18-hydroxycorticosterone $<100 \mathrm{ng} / \mathrm{dl}(24)$ in IHA $(8 / 9)$ but not in APA $(1 / 5) ;(c)$ bilateral uptake on adrenal iodocholesterol scan (37, 38 ) in IHA (9/9) but not in APA (0/5); and (d) symmetrical adrenal vein aldosterone sampling $(39,40)$ in IHA $(5 / 5)$ but not in APA (1/4). Four APA patients underwent surgery, which confirmed the diagnosis. The fifth APA patient refused surgery.

In assessing the pituitary-adrenal axis, neither the concentration of plasma IR-ACTH nor plasma cortisol (Table I) differed significantly between any of the groups, either at 0800 or $1200 \mathrm{~h}$. Urinary-free cortisol levels were also unremarkable (Table I). However, in IHA, the mean plasma IR- $\gamma-\mathrm{MSH}$ concentration $(90 \pm 17 \mathrm{fmol} / \mathrm{ml}$; range: $13-173 \mathrm{fmol} / \mathrm{ml})$ was significantly elevated $(P<0.05)$ at $0800 \mathrm{~h}$ (supine), as compared with the mean levels in EH $(33 \pm 6 \mathrm{fmol} / \mathrm{ml})$, APA $(33 \pm 8 \mathrm{fmol} /$ $\mathrm{ml}$ ), and $\mathrm{NC}(19 \pm 2 \mathrm{fmol} / \mathrm{ml}$ ) (Fig. 1). At $1200 \mathrm{~h}$ (upright), the mean plasma IR- $\gamma$-MSH was significantly higher in both IHA $(95 \pm 26 \mathrm{fmol} / \mathrm{ml}$; range: $6-202 \mathrm{fmol} / \mathrm{ml})$ and APA $(63 \pm 23$ $\mathrm{fmol} / \mathrm{ml}$; range: $5-131 \mathrm{fmol} / \mathrm{ml})$, as compared with EH $(31 \pm 6$ $\mathrm{fmol} / \mathrm{ml}$ ) and $\mathrm{NC}(19 \pm 3 \mathrm{fmol} / \mathrm{ml})$ (Fig. 1). Two IHA subjects with very high IR- $\gamma$-MSH levels $(252$ and $112 \mathrm{fmol} / \mathrm{ml})$ had evidence of pituitary disease; in one case, a chromophobe pituitary adenoma, and in the other an enlarged sella turcica for which further diagnostic evaluation was declined. Of the nine EH patients, five had IR- $\gamma$-MSH levels within the normal range $(<35 \mathrm{fmol} / \mathrm{ml})$. Among the $\mathrm{EH}$ patients with elevated plasma IR- $\gamma$-MSH levels, two of these $(57$ and $51 \mathrm{fmol} / \mathrm{ml}$ at $0800 \mathrm{~h}$ ) also had low PRA (0.1 $\mathrm{ng} \mathrm{AI} / \mathrm{ml}$ per h upright and postfurosemide) and relatively high ASR (123 and $133 \mu \mathrm{g} / \mathrm{d})$.

Three of five APA patients had normal IR- $\gamma$-MSH levels, while two patients had $1200 \mathrm{~h}$ IR- $\gamma$-MSH concentrations $>100 \mathrm{fmol} / \mathrm{ml}$. In order to evaluate the potency of a pro- $\gamma-$ MSH as an aldosterone secretogogue in vitro, an adrenal tumor from one of the latter APA subjects (patient B1: IR- $\gamma$ $\mathrm{MSH}, 131 \mathrm{fmol} / \mathrm{ml}$; aldosterone, $56 \mathrm{ng} / \mathrm{dl}$ ), as well as another tumor from an APA patient (B2) with low plasma IR- $\gamma$-MSH 
Table I. Diagnostic Data By Subject Group

\begin{tabular}{|c|c|c|c|c|}
\hline Index & $\begin{array}{l}\text { Limits of } \\
\text { normal range }\end{array}$ & EH & APA & IHA \\
\hline Systolic BP $(m m H g)$ & & $157 \pm 8.8$ & $156 \pm 8.3$ & $158 \pm 8.9$ \\
\hline Diastolic BP $(m m H g)$ & & $95 \pm 2.2$ & $99 \pm 5.0$ & $97 \pm 3.8$ \\
\hline $\mathrm{K}^{+}$(meq/liter) & $3.6-5.0$ & $3.8 \pm 0.2$ & $3.1 \pm 0.1 \quad(5)^{*}$ & $3.1 \pm 0.1 \quad(9)^{*}$ \\
\hline \multicolumn{5}{|l|}{ PRR (ng $A I / m l$ per $h)$} \\
\hline $0800 \mathrm{~h}$, supine & $0.6-1.2$ & $1.0 \pm 0.3$ & $0.2 \pm 0.1 \quad(5)^{*}$ & $0.3 \pm 0.1 \quad(9)^{*}$ \\
\hline $1200 \mathrm{~h}$, upright & $1.2-2.2$ & $2.0 \pm 0.7$ & $0.4 \pm 0.2(5)^{*}$ & $0.5 \pm 0.2(9)^{*}$ \\
\hline Postfurosemide & $2.5-6.3$ & $4.5 \pm 1.9$ & $0.3 \pm 0.2 \quad(3)^{*}$ & $0.5 \pm 0.2(9)^{*}$ \\
\hline \multicolumn{5}{|c|}{ Plasma aldosterone $(n g / d l)$} \\
\hline $0800 \mathrm{~h}$, supine & $4-11$ & $7 \pm 0.8$ & $33 \pm 9.4 \quad(5)^{*}$ & $17 \pm 2.2(9)^{*}$ \\
\hline $1200 \mathrm{~h}$, upright & $10-33$ & $24 \pm 4.8$ & $28 \pm 10.2(5)$ & $28 \pm 5.8$ \\
\hline Postfurosemide & $30-50$ & $22 \pm 4.6 \quad(8)$ & $34 \pm 9.0$ & $24 \pm 6.4 \quad(6)$ \\
\hline $\operatorname{ASR}(\mu g / d)$ & $50-150$ & $137 \pm 22.3(8)$ & $282 \pm 49.2(5)^{*}$ & $256 \pm 26.3(9)^{*}$ \\
\hline \multicolumn{5}{|l|}{ Plasma cortisol $(\mu g / d l)$} \\
\hline $0800 \mathrm{~h}$, supine & $4-22$ & $14 \pm 1.3$ & $25 \pm 4.2$ & $13 \pm 1.6 \quad(9)$ \\
\hline $1200 \mathrm{~h}$, upright & $4-18$ & $10 \pm 1.1$ & $22 \pm 4.4$ & $12 \pm 2.4$ \\
\hline $\mathrm{UFC}(\mu g / d)$ & $15-50$ & $28 \pm 8.4$ & $44 \pm 6.8$ & $41 \pm 6.1$ \\
\hline \multicolumn{5}{|c|}{ 18-Hydroxycorticosterone $(\mu g / d l)$} \\
\hline $0800 \mathrm{~h}$, supine & $15-50$ & $20 \pm 4.7$ & $130 \pm 45.5(5)^{*}$ & $46 \pm 7.7 \quad(9)^{*}$ \\
\hline $1200 \mathrm{~h}$, upright & $15-50$ & $53 \pm 11.5(9)$ & $114 \pm 33.2(5)^{*}$ & $59 \pm 16.7(9)$ \\
\hline Postfurosemide & $15-50$ & $37 \pm 6.0$ & $143 \pm 52.5(4)^{*}$ & $63 \pm 15.4(5)$ \\
\hline \multicolumn{5}{|c|}{ Plasma IR-ACTH $(\mathrm{fmol} / \mathrm{ml})$} \\
\hline $0800 \mathrm{~h}$, supine & $<9.9$ & $8.6 \pm 0.9$ & $7.6 \pm 1.8$ & $7.9 \pm 0.7$ \\
\hline $1200 \mathrm{~h}$, upright & $<10.8$ & $8.0 \pm 0.7$ & $8.0 \pm 1.1$ & $7.4 \pm 0.7$ \\
\hline \multicolumn{5}{|c|}{ Plasma IR- $\gamma$-MSH $(\mathrm{fmol} / \mathrm{ml})$} \\
\hline $0800 \mathrm{~h}$, supine & $<29$ & $33 \pm 6.5 \quad$ (9) & $33 \pm 7.7$ & $90 \pm 17.1(9)^{*}$ \\
\hline $1200 \mathrm{~h}$, upright & $<35$ & $31 \pm 6.4$ & $63 \pm 22.7(5)^{*}$ & $95 \pm 26.1(9)^{*}$ \\
\hline
\end{tabular}

Values are $\overline{\mathrm{x}} \pm \mathrm{SE}(n)$. UFC, urinary free cortisol; BP, blood pressure; AI, angiotensin I. Numbers in parentheses indicate number of subjects. ${ }^{*} P<0.05$ vs. EH.

(12 fmol/ml) and aldosterone (10 $\mathrm{ng} / \mathrm{dl})$, was obtained at adrenalectomy. Incubation of the dispersed adenoma cells with human Lys- $\gamma 3-\mathrm{MSH}\left(10^{-14}-10^{-9} \mathrm{M}\right)$ produced a dose-dependent increase (approximately fourfold) in aldosterone secretion by cells from B1 but not by those from B2 (Fig. 2). Both sets of cells were viable by the criterion of Trypan blue exclusion.

\section{Discussion}

The results of this study demonstrate that circulating IR- $\gamma-$ MSH is significantly increased in a major subgroup of patients with IHA, as compared with the mean levels observed in APA, EH, and NC. Six of nine IHA patients, two with evidence of pituitary disease, had plasma IR- $\gamma$-MSH concentrations $>80$ $\mathrm{fmol} / \mathrm{ml}$, well above the upper limit of our normal range.

In contrast, Gullner et al. (41) failed to observe elevated IR- $\gamma$-MSH in either of the two IHA subjects they tested. Their negative findings may reflect the small sample size, since two IHA patients in the present study also exhibited normal IR- $\gamma$ MSH levels. Alternatively, the differing results may be a function of differences in the $\gamma$-MSH antisera employed. To illustrate, Gullner and colleagues (41) reported concentrations of IR- $\gamma$-MSH approximately equimolar with those of IRACTH in the plasma of their subjects. Although this would not be entirely unexpected, since both polypeptides are generated by cleavage from the same pituitary prohormonePOMC - we and others (42) have found the molar concentrations of circulating IR- $\gamma$-MSH to be severalfold higher than IR-ACTH. Physiologically, this could be explained by differing rates of metabolic clearance for ACTH and pro- $\gamma$-MSH, as in the rat (43). There have been no reports that any circulating pro- $\gamma$-MSH is derived from a non-POMC precursor.

The coincidental elevations of plasma IR- $\gamma$-MSH and aldosterone in IHA can be interpreted in several ways. First, they may be epiphenomena with no causal relationship. Although this cannot be ruled out, there is evidence that in certain settings pro- $\gamma$-MSHs can modulate aldosterone secretion. For example, pro- $\gamma$-MSHs potentiate the effect of ACTH on aldosterone secretion by the rat adrenal cortex in vitro (17) and in vivo (18), and we have previously demonstrated specific, high-affinity receptors for a pro- $\gamma$-MSH on the plasma membrane of the rat adrenal cortex (44). Moreover, a substantial, 
Table II. Diagnostic Data for Subjects with Idiopathic Hyperaldosteronism

\begin{tabular}{|c|c|c|c|c|c|c|c|c|c|}
\hline Patient & D.J. & T.A. & B.C. & G.D. & E.G. & E.S. & H.W. & R.H. & R.J. \\
\hline Gender & $\mathbf{F}$ & $\mathrm{F}$ & $\mathrm{F}$ & $\mathrm{F}$ & $\mathrm{F}$ & $\mathbf{M}$ & $\mathbf{M}$ & $\mathbf{M}$ & $\mathbf{M}$ \\
\hline Age & 34 & 53 & 56 & 46 & 60 & 70 & 58 & 50 & 32 \\
\hline $\mathrm{BP}(m m H g)$ & $180 / 110$ & $130 / 90$ & $150 / 100$ & $140 / 90$ & $160 / 90$ & $160 / 100$ & $130 / 84$ & $220 / 120$ & $150 / 86$ \\
\hline $\mathrm{K}^{+}($meq/liter $)$ & 3.1 & 3.0 & 3.2 & 3.2 & 3.1 & 3.2 & 3.5 & 3.1 & 2.6 \\
\hline \multicolumn{10}{|c|}{ PRA $(n g A I / m l p e r h)$} \\
\hline $0800 \mathrm{~h}$, supine & 0.5 & 0.5 & 0.9 & 0.1 & 0.2 & 0.1 & 0.1 & 0.6 & 0.1 \\
\hline $1200 \mathrm{~h}$, upright & 0.7 & 0.6 & 1.5 & 0.1 & 0.2 & 0.1 & 0.1 & 0.9 & 0.1 \\
\hline Postfurosemide & 1.2 & 0.6 & 1.2 & 0.1 & 0.2 & 0.1 & 0.1 & 1.3 & 0.1 \\
\hline \multicolumn{10}{|l|}{ Aldosterone $(n g / d l)$} \\
\hline $0800 \mathrm{~h}$, supine & 25 & 17 & 9 & 22 & 10 & 9 & 16 & 22 & 28 \\
\hline $1200 \mathrm{~h}$, upright & 52 & 11 & 29 & 51 & 17 & 18 & 28 & 52 & 12 \\
\hline $\operatorname{ASR}(\mu g / d)$ & 206 & 267 & 231 & 344 & 159 & 241 & 187 & 430 & 236 \\
\hline \multicolumn{10}{|l|}{ Cortisol $(\mu g / d l)$} \\
\hline $0800 \mathrm{~h}$, supine & 20 & 12 & 21 & 10 & 13 & 9 & 6 & 16 & 9 \\
\hline $1200 \mathrm{~h}$, upright & 27 & 11 & 14 & 10 & 8 & 7 & 8 & 23 & 4 \\
\hline \multicolumn{10}{|c|}{ 18-Hydroxycorticosterone $(n g / d l)$} \\
\hline $0800 \mathrm{~h}$, supine & 72 & 57 & 67 & 52 & 29 & 15 & 16 & 31 & 79 \\
\hline $1200 \mathrm{~h}$, upright & 180 & 39 & 15 & 95 & 45 & 24 & 17 & 35 & 81 \\
\hline \multicolumn{10}{|c|}{ IR-ACTH $(\mathrm{fmol} / \mathrm{ml})$} \\
\hline $0800 \mathrm{~h}$, supine & 11.2 & 4.6 & 8.1 & 5.9 & 10.1 & 6.4 & 9.5 & 6.8 & 8.7 \\
\hline $1200 \mathrm{~h}$, upright & 10.0 & 4.2 & 7.9 & 3.9 & 9.1 & 6.1 & 9.0 & 9.7 & 7.0 \\
\hline \multicolumn{10}{|c|}{ IR- $\gamma$-MSH $(\mathrm{fmol} / \mathrm{ml})$} \\
\hline $0800 \mathrm{~h}$, supine & 173 & 88 & 91 & 164 & 87 & 29 & 108 & 13 & 55 \\
\hline $1200 \mathrm{~h}$, upright & 202 & 91 & 71 & 252 & 62 & 6 & 112 & 20 & 36 \\
\hline
\end{tabular}

Limits of the normal range for each of the assays appear in Table I. All patients in this group had bilateral uptake on adrenal iodocholesterol scan and symmetric adrenal morphology by abdominal computed axial tomography. Of the five subjects who underwent adrenal venous sampling (D.J., T.A., H.W., R.H., R.J.), all had nonlateralizing aldosterone levels. BP, blood pressure; M/F, male/female; AI, angiotensin I.

independent tropic effect on aldosterone secretion from dispersed adrenal adenoma cells has been demonstrated in this study and elsewhere $(45,46)$ using synthetic human Lys- $\gamma 3$ MSH, and by Chretien and colleagues $(16,46)$ with a human pro- $\gamma$-MSH. Although glucocorticoid biosynthesis is also stimulated by this hormone, there is some evidence $(18,45)$ that at physiologically relevant concentrations, pro- $\gamma$-MSHs are selectively more potent as aldosterone secretogogues. This may

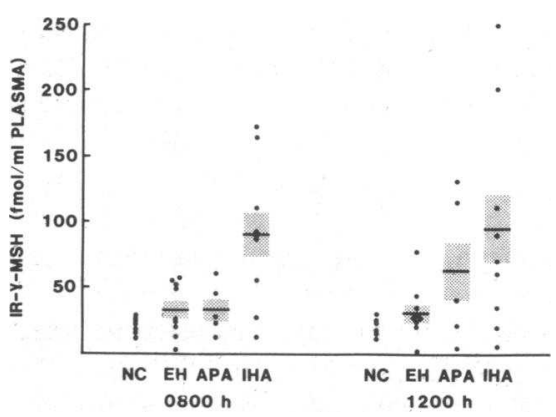

Figure 1. Plasma IR- $\gamma$-MSH levels at $0800 \mathrm{~h}$ (supine) and $1200 \mathrm{~h}$ (upright) in IHA, APA, EH, and NC. Crossbars and shaded regions represent group $\mathrm{x} \pm \mathrm{SE}$. explain why cortisol levels are unremarkable in the IHA subjects. It is also noteworthy that based on data from compensatory adrenal hypertrophy studies in the rat, Lowry et al. (19) have invoked an adrenal hypertrophic role for pro- $\gamma$ $\mathrm{MSH}$, while another group has reported that infusion of an

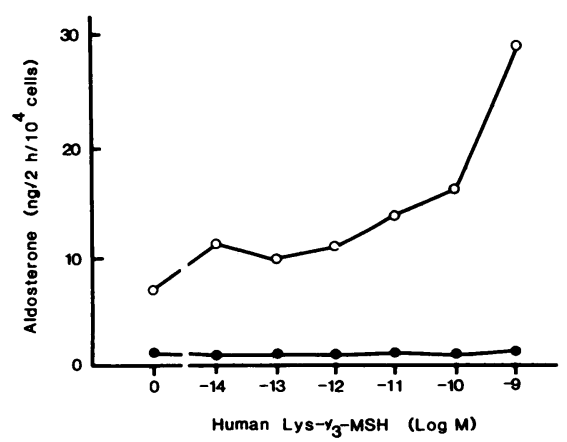

Figure 2. Aldosterone response to graded doses of synthetic human Lys- $\gamma 3$-MSH by dispersed adrenal adenoma cells from two subjects, one with high plasma IR- $\gamma-\mathrm{MSH}$ and aldosterone levels (patient B1; open circles), and a second with low values (patient B2; closed circles). 
anti- $\gamma$-MSH antiserum into spontaneously hypertensive and WKY rats blocks the positive effect of ACTH on aldosterone secretion (47).

Even if a causal relationship should exist between increased pro- $\gamma$-MSH and aldosterone in IHA, it could be argued that the pituitary response is secondary to an augmented aldosterone production mediated by some other secretogogue. Specific mineralocorticoid receptors have been reported in the pituitary $(48,49)$, but their role is unknown. However, we have found no significant effect of chronic aldosterone administration on pituitary or circulating pro- $\gamma-\mathrm{MSH}$ in the rat (Pedersen, $\mathrm{R}$. C., and $A$. C. Brownie, unpublished observations). Moreover, the normal IR- $\gamma$-MSH levels in two of our subjects with IHA and three of five with APA suggest it is unlikely that elevated pro$\gamma$-MSH is a secondary response to hyperaldosteronism.

Sen and colleagues $(50,51)$ have partially characterized an ASF which has several characteristics in common with the major human pro- $\gamma$-MSH. For example, both are pituitary glycoproteins, and the mean plasma concentrations of their ASF in normotensives and patients with IHA (31 and 71 $\mathrm{fmol} / \mathrm{ml}$, respectively) (52) are remarkably similar to the values for pro- $\gamma$-MSH reported here. Both appear to mediate their effects by a mechanism(s) that is independent of cAMP (44, 53). Carey et al. (52) have reported that an antiserum to ASF does not cross-react with synthetic human Lys- $\gamma 3-\mathrm{MSH}$, but data concerning the converse-the affinity of an anti- $\gamma-\mathrm{MSH}$ antibody for ASF-are not available.

There is a disparity between the molecular weights reported by Sen et al. for ASF $(\sim 26,000)(6)$ and the major form of human pro- $\gamma$-MSH $(\sim 12,000)$. However, from preliminary data obtained using size exclusion HPLC (Pedersen, R. C., and A. C. Brownie, unpublished observations), we believe that much of the increased plasma IR- $\gamma$-MSH in our IHA subjects may be of higher molecular weight than the predominant pro$\gamma$-MSH $(54,55)$ observed in normotensive controls. This high molecular weight material, perhaps reflecting incompletely processed forms of POMC, appears to cross-react poorly with the ACTH antiserum, a fact which may explain why IHA plasma IR-ACTH values are within the normal range, while both IR- $\gamma$-MSH (this study) and IR- $\beta$-endorphin levels (56) are elevated. An intermediate in POMC processing $(22,000$ mol wt ACTH; ACTH biosynthetic intermediate), consisting of the $\mathrm{NH}_{2}$-terminal region of POMC and ACTH still intact, is reported to be a potent agonist and synergist of aldosterone secretion in vitro (57).

Increased ASF levels have been reported not only in IHA but also in low renin EH. Two EH patients in the present study had high IR- $\gamma$-MSH levels (>50 fmol/ml) and low renin hypertension. The PRA levels in these patients were suppressed ( $<0.1 \mathrm{ng} \mathrm{AI} / \mathrm{ml}$ per $\mathrm{h}$ upright and postfurosemide), but their aldosterone secretion rates were relatively high (122 and 133 $\mu \mathrm{g} / \mathrm{d}$ ). Previous studies (4) have demonstrated that subjects with low renin EH, like IHA, have augmented aldosterone secretogogue responses and elevated levels of ASF by bioassay. Except for the level of aldosterone production, low renin EH cannot be differentiated from IHA, and it has been postulated $(58,59)$ that these diseases are part of a continuum rather than distinct entities. If this is true, and if pro- $\gamma$-MSH is etiologic, it is possible that excess pro- $\gamma$-MSH results first in low renin, normal aldosterone $\mathrm{EH}$, and later evolves to IHA as aldosterone production increases.

Recently, it has been suggested (60) that IHA may be an abnormality of the pars intermedia. In normal adults this region of the pituitary is usually difficult to discern, but it can be identified by histochemical staining (61). In man, less information is available concerning POMC processing and secretory control from cells in this region as compared with corticotrophs in the anterior pituitary, but studies in other species have demonstrated substantial differences (62). For example, there is evidence that the release of POMC-derived products from the intermediate zone may be under serotonergic (stimulatory) and dopaminergic (inhibitory) control, and is not responsive to feedback inhibition by glucocorticoids. It is noteworthy, therefore, that cyproheptadine, a serotonin antagonist, lowers aldosterone production in IHA but not in APA or NC (63). Conversely, in a patient with IHA, administration of levodopa reportedly reversed the clinical manifestations of the disorder, including the elevated levels of urinary and plasma ASF (64). In the study by Gullner et al. (41) cited above, dexamethasone paradoxically failed to suppress the levels of IR- $\gamma$-MSH in their IHA subjects. In view of the possibility that pro- $\gamma$-MSH could be of pars intermedia origin, or even nonpituitary (see, for example, references 65-67), the exact source of the elevated plasma IR- $\gamma$-MSH observed in some subjects of this study would be of considerable interest.

In conclusion, we have found that circulating plasma IR$\gamma$-MSH levels are significantly elevated in a major subset of patients with IHA. Two of the IHA patients with the highest levels had pituitary abnormalities, which raises the possibility of an associated pituitary disorder. Among the EH subjects tested, the two with increased IR- $\gamma$-MSH levels also had low renin hypertension and inappropriately high-normal aldosterone secretion rates. Although florinef suppression was not attempted, it is possible that these two patients had indeterminant or evolving hyperaldosteronism $(2,68,69)$. Together with accumulated data demonstrating that pro- $\gamma$-MSHs can stimulate or potentiate aldosterone secretion under certain circumstances, these findings suggest the possibility that pro- $\gamma$-MSH may be a significant etiological factor in some forms of hyperaldosteronism.

\section{Acknowledgments}

We are grateful for the technical expertise of Thomas E. Wilson, Diane Rice, Patricia Flynn, Mary Pietra Russo, Judith Colby, and Robert Linsmair. We would also like to thank Mary Mulready, R.N.; Gladys Burroughs, L.P.N.; and Joan Downey for clinical monitoring on the Metabolic Unit.

This study was supported in part by U. S. Public Health Service grants RR533, AM12027, AM18141, AM21683, HL06975, HL07224, and HL18318. Dr. Griffing is the recipient of a New Investigator Research Award (HL31049), and Dr. Pedersen is the recipient of a Research Career Development Award (HD00613).

\section{References}

1. Biglieri, E. G., M. Schambelan, P. E. Slaton, and J. R. Stockigt. 1970. The intercurrent hypertension of primary aldosteronism. Circ. Res. 27(Suppl. 1):I195-1202.

2. Baer, L., S. C. Sommers, L. R. Krakoff, M. A. Newton, and J. H. Laragh. 1970. Pseudo primary aldosteronism: an entity distinct from true primary aldosteronism. Circ. Res. 27(Suppl. 1);1203-I216.

3. Nicholls, M. G., E. A. Espiner, H. Hughes, J. Ross, and D. T. Stewart. 1975. Primary aldosteronism: a study in contrasts. Am. J. Med. 59:334-342.

4. Brown, R. D., M. Wisgerhof, P. C. Carpenter, G. Brown, N.-S. 
Jiang, P. Kao, and R. Hegstad. 1979. Adrenal sensitivity to angiotensin II and undiscovered aldosterone stimulating factors in hypertension. J. Steroid Biochem. 11:1043-1050.

5. Sen, S., F. M. Bumpus, S. Ovverfield, and M. I. New. 1983. Development and preliminary application of a new assay for aldosterone stimulating factor. Hypertension. 5(Suppl. 1):I27-131.

6. Sen, S., R. Valenzuela, R. Smeby, E. L. Bravo, and F. M Bumpus. 1981. Localization, purification, and biologic activity of a new aldosterone-stimulating factor. Hypertension. 3(Suppl. 1):I81-I86.

7. Vinson, G. P., B. J. Whitehouse, A. Dell, T. Etienne, and H. R. Morris. 1980. Characterization of an adrenal zona glomerulosa-stimulating component of posterior pituitary extracts as $\alpha-\mathrm{MSH}$. Nature (Lond.). 284:464-467.

8. $\mathrm{Li}, \mathrm{C} . \mathrm{H} ., \mathrm{T}$. B. $\mathrm{Ng}$, and C. H. Cheng. 1982. Melanotropins: aldosterone- and corticosterone-stimulating activity in isolated rat adrenal cells. Int. J. Pept. Protein Res. 19:361-365.

9. Matsuoka, H., P. J. Mulrow, and C. H. Li. 1980. $\beta$-lipotropin: A new aldosterone-stimulating factor. Science (Wash. DC). 209:307308.

10. Matsuoka, H., P. J. Mulrow, R. Franco-Saenz, and C. H. Li. 1981. Stimulation of aldosterone production by $\beta$-melanotropin. Nature (Lond.). 291:155-156.

11. Yamakado, M., R. Franco-Saenz, and P. J. Mulrow. 1983. Effect of sodium deficiency on $\beta$-melanocyte stimulating hormone stimulation of aldosterone in isolated rat adrenal cells. Endocrinology. 113:2168-2172.

12. Washburn, D. D., D. C. Kem, D. N. Orth, W. E. Nicholson, M. Chretien, and C. V. Mount. 1982. Effect of $\beta$-lipotropin on aldosterone production in the isolated rat adrenal cell preparation. J. Clin. Endocrinol. Metab. 54:613-617.

13. Gullner, H. G., and J. R. Gill, Jr. 1983. $\beta$-endorphin selectively stimulates aldosterone secretion in hypophysectomized, nephrectomized dogs. J. Clin. Invest. 71:124-128.

14. Szalay, K. S., and E. Stark. 1981. Effect of $\beta$-endorphin on the steroid production of isolated zona glomerulosa and zona fasciculata. Life Sci. 29:1355-1361.

15. Nakanishi, S., A. Inoue, T. Kita, M. Nakamura, A. C. Y. Chang, and S. Cohen. 1979. Nucleotide sequence of cloned cDNA for bovine corticotropin- $\beta$-lipotropin precursor. Nature (Lond.). 278:423427.

16. Lis, M., P. Hamet, J. Gutkowska, G. Maurice, N. G. Seidah, B. Lariviere, M. Chretien, and J. Genest. 1981. Effect of N-terminal portion of proopiomelanocortin on aldosterone release by human adrenal adenoma in vitro. J. Clin. Endocrinol. Metab. 52:1053-1056.

17. Al-Dujaili, E. A. S., J. Hope, F. E. Estivariz, P. J. Lowry, and C. R. W. Edwards. 1981. Circulating human pituitary pro- $\gamma$-melanotropin enhances the adrenal response to ACTH. Nature (Lond.). 291: 156-159.

18. Pedersen, R. C., A. C. Brownie, and N. Ling. 1980. Proadrenocorticotropin/endorphin-derived peptides: coordinate action on adrenal steroidogenesis. Science (Wash. DC). 208:1044-1045.

19. Lowry, P. J., L. Silas, C. McLean, E. A. Linton, and F. E. Estivariz. 1983. Pro- $\gamma$-melanocyte-stimulating hormone cleavage in adrenal gland undergoing compensatory growth. Nature (Lond.). 306 70-73.

20. Kirdendall, W. M., J. J. Hammond, J. C. Thomas, M. L. Overturf, and A. Zama. 1976. Prazosin and clonidine for moderately severe hypertension. J. Am. Med. Assoc. 240:2553-2556.

21. White, E. A., M. Schambelan, C. R. Rost, E. G. Biglieri, A. A Moss, and M. Korobkin. 1980. Use of computed tomography in diagnosing the cause of primary aldosteronism. N. Engl. J. Med. 303 1503-1507.

22. Korobkin, M., E. A. White, H. Y. Dressel, A. A. Moss, and J. P. Montagne. 1979. Computed tomography in the diagnosis of adrenal disease. Am. J. Radiol. 132:231-238.

23. Anonymous. 1984. The 1984 report of the Joint National Committee on Detection, Evaluation, and Treatment of High Blood Pressure. Arch. Intern. Med. 144:1045-1057.
24. Biglieri, E. G., M. Schambelan, J. Hirai, B. Chang, and N. Brust. 1979. The significance of elevated levels of plasma 18-hydroxycorticosterone in patients with primary aldosteronism. J. Clin. Endocrinol. Metab. 49:87-91.

25. Foster, L. B., and R. T. Dunn. 1974. Single antibody technique for radioimmunoassay of cortisol in unextracted serum or plasma. Clin. Chem. 20:365-368.

26. Antunes, J. R., S. L. Dale, and J. C. Melby. 1976. Simplified radioimmunoassays for aldosterone using antisera to aldactone- $\gamma$ lactone. Steroids. 28:621-630.

27. Haber, E., T. Koerner, L. B. Page, B. Kliman, and A. Purnode. 1969. Application of a radioimmunoassay for angiotensin-I to the physiologic measurements of plasma renin activity in normal human subjects. J. Clin. Endocrinol. Metab. 29:1349-1355.

28. Pratt, J. H., M. M. Holbrook, S. L. Dale, and J. C. Melby. 1977. The measurement of urinary tetrahydroaldosterone by radioimmunoassay. J. Steroid Biochem. 8:677-681.

29. Pedersen, R. C., N. Ling, and A. C. Brownie. 1982. Immunoreactive $\gamma$-melanotropin in rat pituitary and plasma: a partial characterization. Endocrinology. 110:825-834.

30. Ling, N., S. Ying, S. Minick, and R. Guillemin. 1979. Synthesis and biological activity of four $\gamma$-melanotropin peptides derived from the cryptic region of the adrenocorticotropin/ $\beta$-lipotropin precursor. Life Sci. 25:1773-1780.

31. Hale, A. C., S. J. Ratter, S. J. Tomlin, N. Lytras, G. M. Besser, and L. H. Rees. 1984. Measurement of immunoreactive $\gamma$-MSH in human plasma. Clin. Endocrinol. 21:139-148.

32. Nicholson, W. E., D. R. Davis, B. J. Sherrell, and D. N. Orth. 1984. Rapid radioimmunoassay for corticotropin in unextracted human plasma. Clin. Chem. 30:259-265.

33. Wallenstein, S., C. L. Zucker, and J. L. Fleiss. 1980. Some statistical methods useful in circulation research. Circ. Res. 47:1-9.

34. Dunnett, C. W. 1964. New tables for multiple comparisons with a control. Biometrics. 20:482-484.

35. Schambelan, M., N. L. Brust, B. C. F. Chang, K. L. Slater, and E. G. Biglieri. 1976. Circadian rhythm and effect of posture on plasma aldosterone concentration in primary aldosteronism. J. Clin. Endocrinol. Metab. 43:115-131.

36. Espiner, C. A., and R. A. Donald. 1980. Aldosterone regulation in primary aldosteronism: influence of salt balance, posture and ACTH. Clin. Endocrinol. 12:277-286.

37. Freitas, J. E., R. J. Grekin, J. H. Thrall, M. D. Gross, D. P. Swanson, and W. H. Beierwaltes. 1979. Adrenal imaging with iodomethyl-norcholesterol (I-131) in primary aldosteronism. J. Nucl. Med. 20:7-10.

38. Anderson, B. G., and J. C. Melby. 1983. Adrenal scintigraphy with ${ }^{131}$ I $6-\beta$-iodomethyl-19nor-cholesterol in primary aldosteronism. J. Nucl. Med. 24:55. (Abstr.)

39. Melby, J. C., R. F. Spark, S. L. Dale, R. H. Egdahl, and P. C. Kahn. 1967. Diagnosis and localization of aldosterone producing adenoma by adrenal vein catheterization. $N$. Engl. J. Med. 277:1050 1056.

40. Weinberger, M. H., C. E. Grim, J. W. Hollifield, D. C. Kem, A. Ganguly, N. J. Kramer, H. Y. Yune, H. Wellman, and J. P. Donohue. 1979. Primary aldosteronism: diagnosis, localization, and treatment. Ann. Int. Med. 90:386-395.

41. Gullner, H. G., W. E. Nicholson, J. R. Gill, Jr., and D. N. Orth. 1983. Plasma amino reactive pro-opiocortin-derived peptides in patients with primary hyperaldosteronism, idiopathic hyperaldosteronism with bilateral adrenal hyperplasia and dexamethasone-suppressible hyperaldosteronism. J. Clin. Endocrinol. Metab. 56:853-855.

42. Chan, J. S. D., N. G. Seidah, N. G., and M. Chretien. 1983. Measurement of $\mathrm{N}$-terminal (1-76) of human proopiomelanocortin in human plasma: correlation with adrenocorticotropin. J. Clin. Endocrinol. Metab. 56:791-796.

43. Lu, C.-L., J. S. D. Chan, A. De Lean, A. Chen, N. G. Seidah, and M. Chretien. 1983. Metabolic clearance rate and half-time disap- 
pearance of human N-terminal and adrenocorticotropin of pro-opiomelanocortin in the rat: a comparative study. Life Sci. 33:2599-2608.

44. Pedersen, R. C., and A. C. Brownie. 1983. Lysine- $\gamma$ 3-melanotropin binds with high affinity to the rat adrenal cortex. Endocrinology. 112:1279-1287.

45. Aurecchia, S. A., A. C. Brownie, R. C. Pedersen, P. Raney, J. Allen, G. T. Griffing, and J. C. Melby. 1982. The effect of ACTH and Lys- $\gamma 3-\mathrm{MSH}$ on aldosterone and cortisol production by adenomatous and non-adenomatous human adrenal tissue in vitro. Clin. Res. 30: 489A. (Abstr.)

46. Schiffrin, E. L., M. Chretien, N. G. Seidah, M. Lis, J. Gutkkowska, M. Cantin, and J. Genest. 1983. Response of human aldosteronoma cells in culture to the $\mathrm{N}$-terminal glycopeptide of pro-opiomelanocortin and $\gamma 3$-MSH. Horm. Metab. Res. 15:181-184.

47. Sharp, B., and J. R. Sowers. 1983. Adrenocortical response to corticotropin is inhibited by $\gamma 3-\mathrm{MSH}$ antisera in normotensive and spontaneously hypertensive rats. Biochem. Biophys. Res. Commun. 110:357-363.

48. Krozowski, Z., and J. W. Funder. 1981. Mineralocorticoid receptors in rat anterior pituitary: towards a redefinition of "mineralocorticoid hormone." Endocrinology. 109:1221-1224.

49. Lim, A. T., K. A. K. Khalid, J. Clements, and J. W. Funder. 1982. Glucocorticoid and mineralocorticoid effects on adrenocorticotropin and $\beta$-endorphin in the adrenalectomized rat. J. Clin. Invest. 69:1191-1198.

50. Sen, S., E. L. Bravo, and F. M. Bumpus. 1977. Isolation of a hypertension-producing compound from normal human urine. Circ. Res. 40(Suppl. 1):15-I10.

51. Sen, S., R. Valenzuela, R. Smeby, E. L. Bravo, and F. M. Bumpus. 1981. Localization, purification, and biological activity of a new aldosterone-stimulating factor. Hypertension. 3(Suppl. 1):I81-I86.

52. Carey, R. M., S. Sen, L. M. Dolan, C. D. Malchoff, and F. M. Bumpus. 1984. Idiopathic hyperaldosteronism. A possible role for aldosterone-stimulating factor. N. Engl. J. Med. 311:94-100.

53. Saito, I., E. L. Bravo, T. Zanella, S. Sen, and F. M. Bumpus. 1981. Steroidogenic characteristics of a new aldosterone-stimulating factor (ASF) isolated from normal human urine. Hypertension. 3:300305.

54. Estivariz, F. E., J. Hope, C. McLean, and P. J. Lowry. 1980. Purification and characterization of a $\gamma$-melanotropin precursor from frozen human pituitary glands. Biochem. J. 191:125-131.

55. Seidah, N. B., J. Rochemont, J. Hamelin, M. Lis, and $\mathbf{M}$. Chretien. 1981. Primary structure of the major human pituitary proopiomelanocortin $\mathrm{NH}_{2}$-terminal glycopeptide. J. Biol. Chem. 256: 7977-7984.

56. Griffing, G., T. McIntosh, B. Berelowitz, M. Hudson, R. Salzman, R. C. Pedersen, A. C. Brownie, and J. C. Melby. 1984. Proopiomelanocortin-derived peptides and idiopathic hyperaldosteronism.
Int. Congr. Endocrinol., 7th, Quebec City, Canada. Excerpta Medica Int. Congr. Series No. 652, Elsevier, Amsterdam. 550. (Abstr.)

57. Hale, A. C., S. J. Ratter, G. M. Besser, and L. H. Rees. 1984. Characterisation and bioactivity of N-pro-opiomelanocortin fragments from tumours associated with Cushing's syndrome. Int. Congr. Endocrinol., 7th, Quebec City, Canada. Excerpta Medica Int. Congr. Series No. 652, Elsevier, Amsterdam. 541. (Abstr.)

58. Padfield, P. L., J. J. Brown, D. Davis, R. Fraser, A. F. Lever, J. J. Morton, and J. I. S. Robertson. 1981. The myth of idiopathic hyperaldosteronism. Lancet. II:83-84.

59. McAreavey, D., G. D. Murray, A. F. Lever, and J. I. S. Robertson. 1983. Similarity of idiopathic aldosteronism and essential hypertension. Hypertension. 5:116-121.

60. Franco-Saenz, R., P. J. Mulrow, and K. Kim. 1984. Idiopathic aldosteronism. A possible disease of the intermediate lobe of the pituitary. J. Am. Med. Assoc. 251:2555-2558.

61. Wilkes, M. M., S. Watkin, R. D. Stewart, and S. S. C. Yen. 1980. Localization and quantitation of $\beta$-endorphin in human brain and pituitary. Neuroendocrinology. 30:113-121.

62. Eipper, B. A., and R. E. Mains. 1980. Structure and biosynthesis of proadrenocorticotropin/endorphin and related peptides. Endocr. Rev. 1:1-27.

63. Gross, M. D., R. J. Grekin, T. C. Gniadek, and J. Z. Villareal. 1981. Suppression of aldosterone by cyproheptadine in idiopathic aldosteronism. N. Engl. J. Med. 305:181-185.

64. Malchoff, C. D., J. Q. Miller, S. Sen, and R. M. Carey. 1984. Reduction of aldosterone stimulating factor and reversal of idiopathic hyperaldosteronism by levodopa. Int. Congr. Endocrinol., 7th, Quebec City, Canada. Excerpta Medica Int. Congr. Series No. 652, Elsevier, Amsterdam. 826. (Abstr.)

65. Orwell, E. S., and J. W. Kendall. 1980. $\beta$-Endorphin and adrenocorticotropin in extrapituitary sites: gastrointestinal tract. Endocrinology. 107:438-442.

66. Clements, J. A., J. W. Funder, K. Tracy, F. J. Morgan, D. J. Campbell, P. Lewis, and M. T. W. Hearn. 1982. Adrenocorticotropin, $\beta$-endorphin, and $\beta$-lipotropin in normal thyroid and lung: possible implications for ectopic hormone secretion. Endocrinology. 111:20972102.

67. Chen, C.-L. C., J. P. Mather, P. L. Morris, and C. W. Bardin. 1984. Expression of pro-opiomelanocortin-like gene in the testis and epididymis. Proc. Natl. Acad. Sci. USA. 81:5672-5675.

68. Biglieri, E. G., M. Schambelan, N. Brust, B. Chang, and M. Hogan. 1974. Plasma aldosterone concentration. Further characterization of aldosterone-producing adenomas. Circ. Res. 34/35(Suppl. 1): I183-I191.

69. Bravo, E. L., R. C. Tarazi, H. P. Dustan, F. M. Fouad, S. C. Textor, R. W. Gifford, and D. G. Vidt. 1983. The changing clinical spectrum of primary aldosteronism. Am. J. Med. 74:641-651. 